\title{
Numerical Simulation of Heat-and-Mass Transfer Processes in the Cooling Passages of a Cylinder Head in a Diesel Locomotive Engine
}

\author{
Fedor I. Abramchuk', Andrey N. Avramenko ${ }^{2 *}$ \\ ${ }^{1}$ Department of Internal Combustion Engines, Kharkov National Automobile and Highway University, \\ Yaroslava Mudrogo st. 25, Kharkov, 61002, Ukraine \\ 2 Department of Hydrogen Power Engineering, A.M. Pidhirnyi Institute for Mechanical Engineering Problems NAS of Ukraine, \\ 2/10 Pozharsky St. Kharkov, 61046, Ukraine \\ * Corresponding author, e-mail: an0100@ukr.net
}

Received: 11 April 2018, Accepted: 06 September 2018, Published online: 12 October 2018

\begin{abstract}
Results are given for the comparative numerical simulation of heat-and-mass transfer processes in the cooling passages of a cylinder head in diesel locomotive engine 16 FN 26/27 running under rated power conditions at different engine boost levels. The advanced numerical methods used are shown to ensure a high degree of accuracy and information content when simulating heat-and-mass transfer processes, and enable evaluating the local values of flow parameters with account of the complex configuration of the flow parts in the cooling passages and the impact of operating parameters. The results show that an increasing boost level of a diesel engine and, respectively, a growing thermal load degrade drastically the conditions of heat rejection from the most thermally stressed zones of the cylinder head - the central part of the bottom face in the area of the injector bore and of the bridge between the bores of exhaust valve seats. The paper assesses the impact of the boost level on the effectiveness of heat rejection from the most thermally stressed areas of the cylinder head of a diesel locomotive engine. Conclusions and recommendations for improving the operating conditions of the cylinder head are given.
\end{abstract}

Keywords

cooling passage, cylinder head, diesel engine, temperature, boost level

\section{Introduction}

Modern engine building is being developed along the lines of improving the ecological characteristics of an ICE, and increasing the boost level and engine life [1-3]. The growing thermal load increases the amount of heat removed to the cooling system and withdrawn with the exhaust. This requires improving the effectiveness of the engine cooling system and calls for computational and experimental research.

The cooling of the coolant intensifies heat transfer from the exposed surfaces and the presence of stagnant zones in the cooling cavity facilitates the formation of a vapour film that degrades heat transfer [4]. The presence of variable areas increases the temperature gradients and facilitates an increasing level of thermal stress in the cylinder head.

Diesel locomotives operate with a locomotive characteristic demonstrating crankshaft revolutions up to
1,000 $\mathrm{min}^{-1}$. This means that the big time of the working cycle along with high values of thermodynamic parameters of the working medium due to a high level of gas turbine supercharging results in a substantial temperature growth in the combustion chamber parts. Reducing the level of the temperatures of parts to increase their reliability is possible only by improving the cooling system.

The development of modern computational methods and software packages using CFD (computational fluid dynamics) technologies enables simulating liquid and gas flow in complex-shape passages and ducts, carburation and combustion processes, formation of toxic components and phase transition processes [3-5]. Advanced numerical methods help predict the effect of different factors on heatand-mass transfer processes in ICE cooling systems with minimal use of resources. 


\section{Review of the literature}

Many researchers have been investigating heat-andmass transfer processes in ICE and in the cylinder head cooling passages [6-12]. Studies [6-8] present the methodology and results of numerical simulation of heat-andmass transfer in the cooling jackets of single and individual ICE cylinder heads.

Thus, by example of an individual cylinder head, it was shown that a $25 \%$ to $100 \%$ engine load build-up would intensify the thermal load on the cooling system and degrade the operating conditions of the cylinder bottom face - one of the most thermal-stressed parts of the combustion chamber [8]. The temperature of the bridge between the bores of the exhaust valves seats at a $25 \%$ load is within $105^{\circ} \mathrm{C}$, and at a $100 \%$ load, it reaches $350{ }^{\circ} \mathrm{C}$. In the peripheral zones of the bottom face, the maximum temperature is $200^{\circ} \mathrm{C}$ [8].

Such a temperature gradient induces considerable thermal strain and thermoelastic stresses of the bottom face and degrades the operating conditions of the cylinder head [8].

Using CFD software packages enables 3D simulation of viscous and turbulent flows of the coolant in the ICE cooling system. To model turbulent coolant flow, studies [6-8] recommend using the $\mathrm{k}-\varepsilon$ turbulence model. It enables simulating turbulent flows with high accuracy in the case of liquid flow in complex-shape passages.

The Woschni formula is used [6-8] to investigate the in-cylinder heat balance, calculate the values of the gas-towall heat transfer coefficients and evaluate the changes in the thermal load on the cylinder head with changing diesel engine running conditions.

Great importance in researching heat transfer processes in combustion chambers of locomotive diesels is attached to the work of Prof. G.B. Rosenblit [13]. Paper [13] investigates the comparative results of calculating the coefficient of heat transfer from gas to the combustion chamber walls, which are calculated using formulas by Nusselt, BierlingNusselt, Stambulianu, Eichelberg, Annand, Woschni and other authors.

The comprehensive approach to investigating heat-andmass transfer processes in the cooling passages of ICE housing parts and investigating the thermal stress-strain state of combustion chamber parts allows predicting with high accuracy and validity the variations in the operating conditions of thermal-stressed parts when running conditions change or the boost level is increased. Studies in this area are topical and help save considerably on time and material expenditures for developing new modifications of ICE or refining the design of existing ones.

\section{Research objective and tasks}

The purpose of research is a comparative computational estimation of the impact of the engine 16FN 26/27 boost level on the heat-and-mass transfer processes in the cooling passages of the cylinder head.

The study included the following tasks:

- Review the literature on methods for simulating heat-and-mass transfer processes in the cooling systems of engines;

- Use computational methods to evaluate the changes in the parameters of the engine operating cycle when the boost level is increased;

- Use manufacturer's drawings to generate a computational domain and grid describing the configuration of the cooling passages in an individual cylinder head of the engine;

- Use the results of computation of the engine operating cycle processes, Annand's formulas and the generalisation of the results of other authors to generate a set of boundary conditions to describe heat-andmass transfer processes in the cooling passages of the cylinder head;

- Use numerical methods to perform comparative simulation of heat-and-mass transfer processes in the cooling passages of the cylinder head with different engine boost levels;

- Draw conclusions and make recommendations on improving the operating conditions of an individual cylinder head of diesel engine 16 FN 26/27 with an increasing boost level.

\section{Basic stages and research results}

The investigation is concerned with heat-and-mass transfer processes in the cooling passages of the individual cylinder

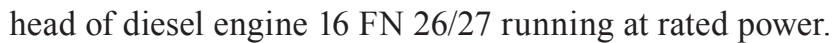
The brief specifications of the engine are shown in Table 1.

The individual cylinder head is a one-piece block special iron casting weighing $92 \mathrm{~kg}$. A horizontal partition divides the cylinder head cooling space into two, the bottom and upper ones. The head has six holes for hold-down studs to fasten the cylinder block. Treated water is used as engine coolant.

\subsection{Computational investigation of the operating cycles of diesel engine 16 FN 26/27}

Methods for diesel engine motoring cycle design and numerical methods [3] were used for designing the operating cycles of the engine running at power $\mathrm{N}_{\mathrm{e}}=2,940$; 
Table 1 Brief specifications of diesel engine 16 FN 26/27

\begin{tabular}{lcc}
\hline Item No. & Parameter & Value \\
\hline 1 & Rated power, $\mathrm{kW}$ & 2,940 \\
2 & Rotational frequency for rated power & \\
& conditions, $\mathrm{min}^{-1}$ \\
3 & Cylinder diameter, $\mathrm{mm}$ & 1,000 \\
4 & Piston stroke, mm & 260 \\
5 & Compression ratio & 270 \\
6 & Number of orifices in injector nozzle & 8 \\
7 & Diameter of injector nozzle orifices, $\mathrm{mm}$ & 0.42 \\
\hline
\end{tabular}

3,100; 3,200 and 3,400 kW. The basic results of comparative computational research are shown in Table 2.

With an increasing engine boost level, the maximum combustion pressure and the temperature of the exhaust gases also increase (Table 2). This intensifies the thermal and mechanical load on combustion chamber parts and degrades their operating conditions.

\subsection{Computational domain and grid}

A computational domain and grid (Fig. 1) were created for numerical simulation of the heat-and-mass transfer processes in the cooling passages of the engine cylinder head. The computational grid was adapted - locally condensed to account for sites with abrupt changes in geometry and for regions with high coolant flow velocities.

Table 2 Basic results of comparative computational research in the operating cycles of the engine

\begin{tabular}{lccccc}
\hline \multirow{2}{*}{ Item No. } & $\mathrm{N}_{\mathrm{e}}$ & $\mathrm{P}_{\mathrm{e}}$ & $\mathrm{P}_{\mathrm{z}}$ & $\mathrm{T}_{\mathrm{g}}$ & $\mathrm{g}_{\mathrm{e}}$ \\
\cline { 2 - 6 } & $\mathrm{kW}$ & $\mathrm{MPa}$ & $\mathrm{MPa}$ & ${ }^{\circ} \mathrm{C}$ & $\mathrm{g} / \mathrm{kWhr}$ \\
\hline 1 & 2,940 & 1.54 & 12 & 590 & 203 \\
2 & 3,100 & 1.62 & 12.6 & 621 & 202 \\
3 & 3,200 & 1.68 & 13 & 645 & 201 \\
4 & 3,400 & 1.78 & 14 & 700 & 199 \\
\hline
\end{tabular}

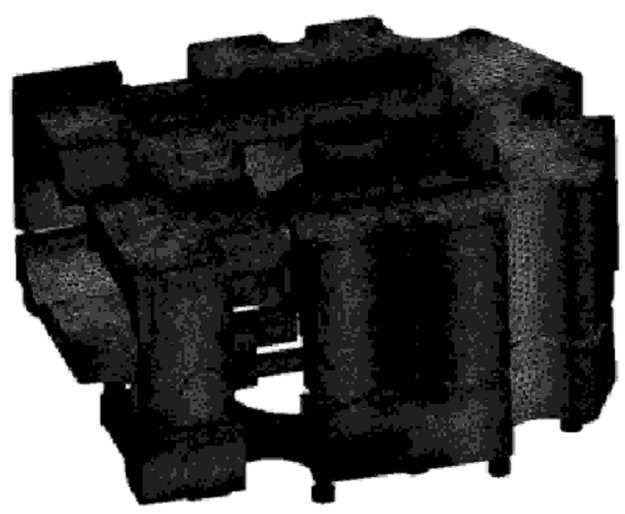

Fig. 1 Computational grid describing the configuration of cooling passages in the cylinder head (3,124,065 computational cells)

\subsection{Description of boundary conditions}

The results of calculating engine running conditions and Annand's formula allowing to account for the change of thermophysical properties of gas and obtain a better fitting of results for the intake and exhaust sections, and the generalisation of other authors' findings were used to create a set of boundary conditions to describe heat-and-mass transfer processes in the cooling passages of the cylinder head, and the type of wall boundary conditions - fixed temperature [6].

Fig. 2 shows the scheme for specifying the boundary conditions at the inlet and outlet of cooling passages in the cylinder head.

According to the data in [14], engines of the D70-D80 line have two pumps in the cooling system (one for each line of cylinders). The point of intersection of the pump delivery curve at the pump impeller rotational frequency of $\mathrm{n}=2,345 \mathrm{~min}^{-1}$ corresponds to the rated diesel engine operating mode with a consumption of $115 \mathrm{~m}^{3} / \mathrm{hr}$ and a pressure of $0.164 \mathrm{MPa}$ [14].

(a)

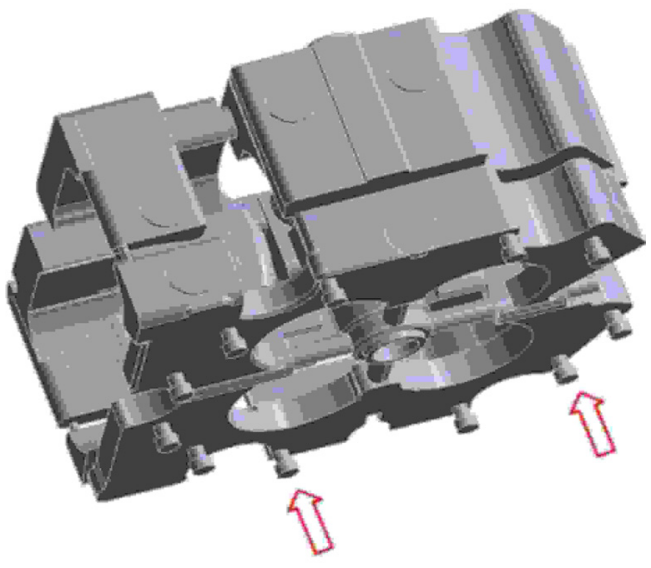

a) Inlet flow ( 11 hole), $\mathrm{V}=1.5 \mathrm{~m} / \mathrm{s}$

(b)

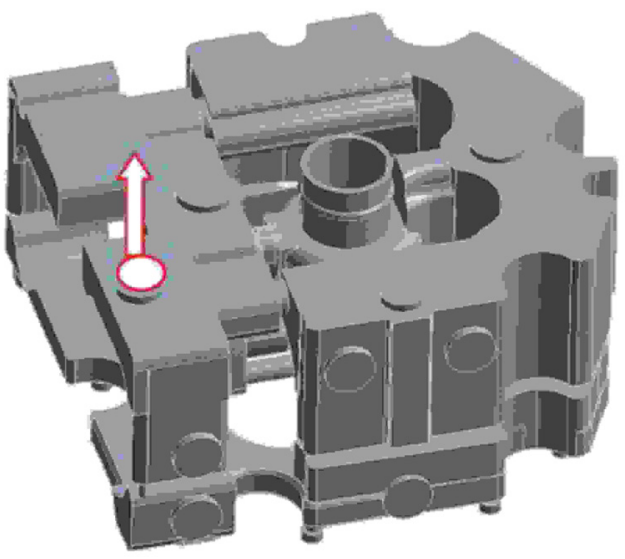

b) Outlet flow (1 hole), $\mathrm{P}=0.14 \mathrm{MPa}$

Fig. 2 Scheme for specifying boundary conditions 
The coolant flows from the jacket in the cylinder block via 11 orifices in the cylinder head bottom face to the bottom cooling space (Fig. 2). Next, the coolant flows via drilled passages in the cylinder head bottom face to the injector cooling space. The coolant also flows upwards via vertical ducts connecting the bottom and upper head cooling spaces. The coolant flows from the upper space via an orifice located above the discharge port (Fig. 2). The coolant pressure in the engine cooling system is $0.16 \mathrm{MPa}$ at rated power conditions.

\subsection{Numerical simulation technique}

The paper considers the real liquid (treated water) flow process in the 3-dimensional nonstationary statement with account of gravity. The $k-\varepsilon$ turbulence model was used to describe turbulent flow with account of recommendations in studies [6-8]. The Total Energy model was used to describe heat transfer between the working medium and the walls. Analysis also accounted for the roughness of solid walls (roughness of $1 \mathrm{~mm}[6]$ ). The study also used the Wall Boiling model and Mixture model [8] to describe possible phase transitions (coolant boiling depending on local conditions - pressure and temperature).

\subsection{Research results}

Fig. 3 shows the velocity distribution of coolant flow in the cylinder head cooling passages $\left(\mathrm{P}_{\mathrm{e}}=1.54 \mathrm{MPa}\right)$. The horizontal section of the drilled passages in the bottom face shows the coolant flow velocity distribution (Fig. 3(a)). The flow velocity reaches $3.5 \mathrm{~m} / \mathrm{s}$ in the region of the drilled passages for cooling the injector and of the ducts for feeding coolant to the bottom space from the cylinder head jacket. In the peripheral regions, the flow velocity changes from 0.5 to $1 \mathrm{~m} / \mathrm{s}$ (Fig. 3(a)). The distribution of the coolant flow velocity in the horizontal section of the upper cylinder head space is shown in Fig. 3(b). The maximum flow velocities were found in the connecting ducts between the areas of the upper cooling space. The distribution of the coolant flow velocity in the vertical section on the injector bore axis is shown in Fig. 3(c). The velocity of the flow around the fuel injector sleeve changes with height from 3.5 to $0.4 \mathrm{~m} / \mathrm{s}$.

The distribution of coolant flow velocity (as a 3D streamline path) is shown in Fig. 3(d). The results presented show that the cooling spaces have no stagnant zones with circulation velocity close to zero.

The distribution of coolant temperature in the cylinder head cooling spaces for different engine boost levels is shown in Fig. 4. The results show that, for a standard boost (a)
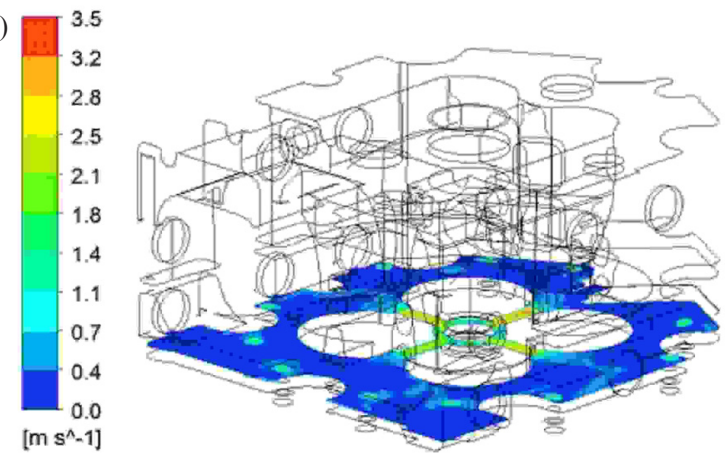

(b)
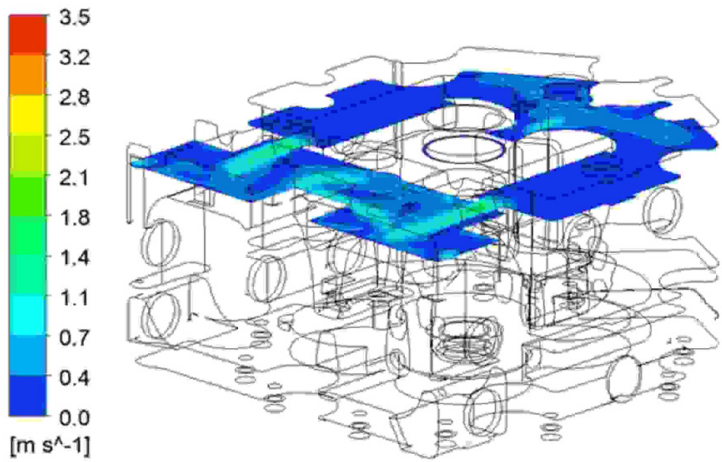

(c)
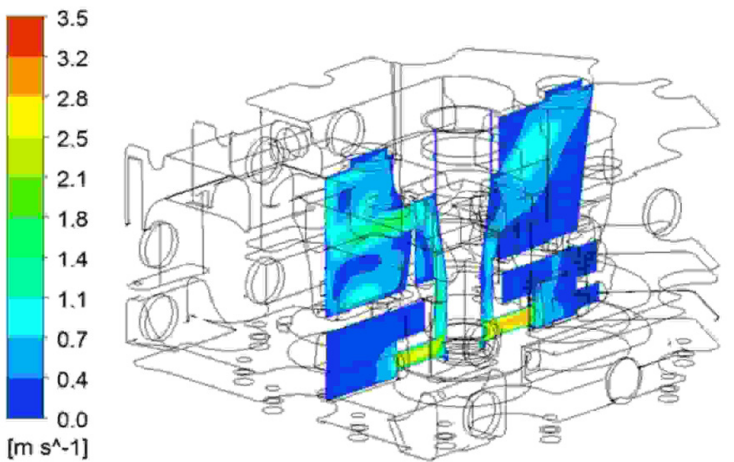

(d)
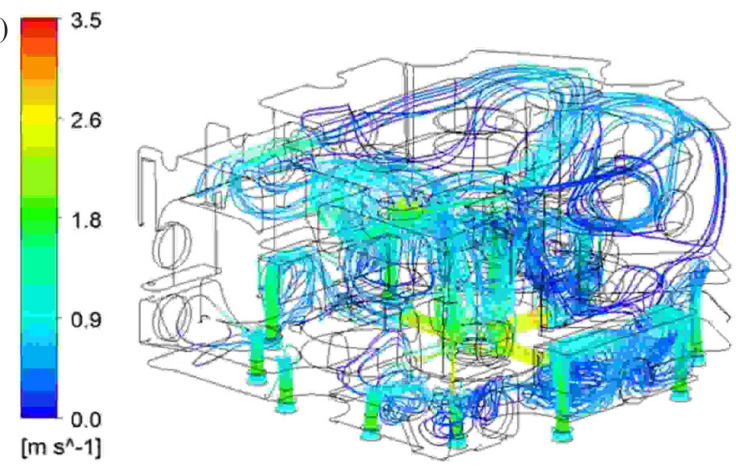

Fig. 3 Distribution of coolant flow velocity in the cylinder head cooling spaces $\left(\mathrm{P}_{\mathrm{e}}=1.54 \mathrm{MPa}\right)$

level of $\mathrm{P}_{\mathrm{e}}=1.54 \mathrm{MPa}$, the coolant temperature varies within $80-100{ }^{\circ} \mathrm{C}$, with the maximum value being $115^{\circ} \mathrm{C}$. The temperature grows with an increasing engine boost level. For the computational variant with $\mathrm{P}_{\mathrm{e}}=1.78 \mathrm{MPa}$, the coolant temperature varies within $115-140{ }^{\circ} \mathrm{C}$. 
(a)

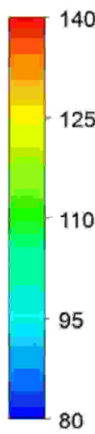

[C]

(b)

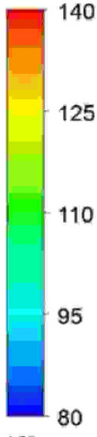

[C]

(c)

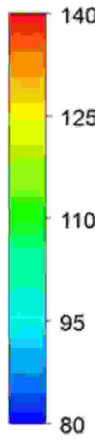

[C]

(d)

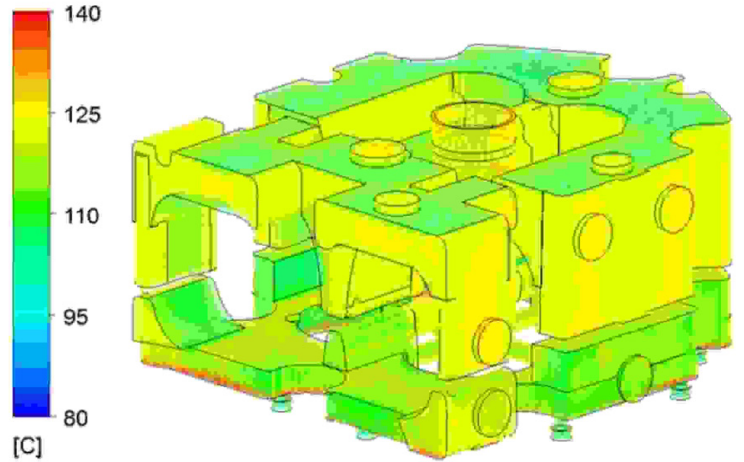

[C]
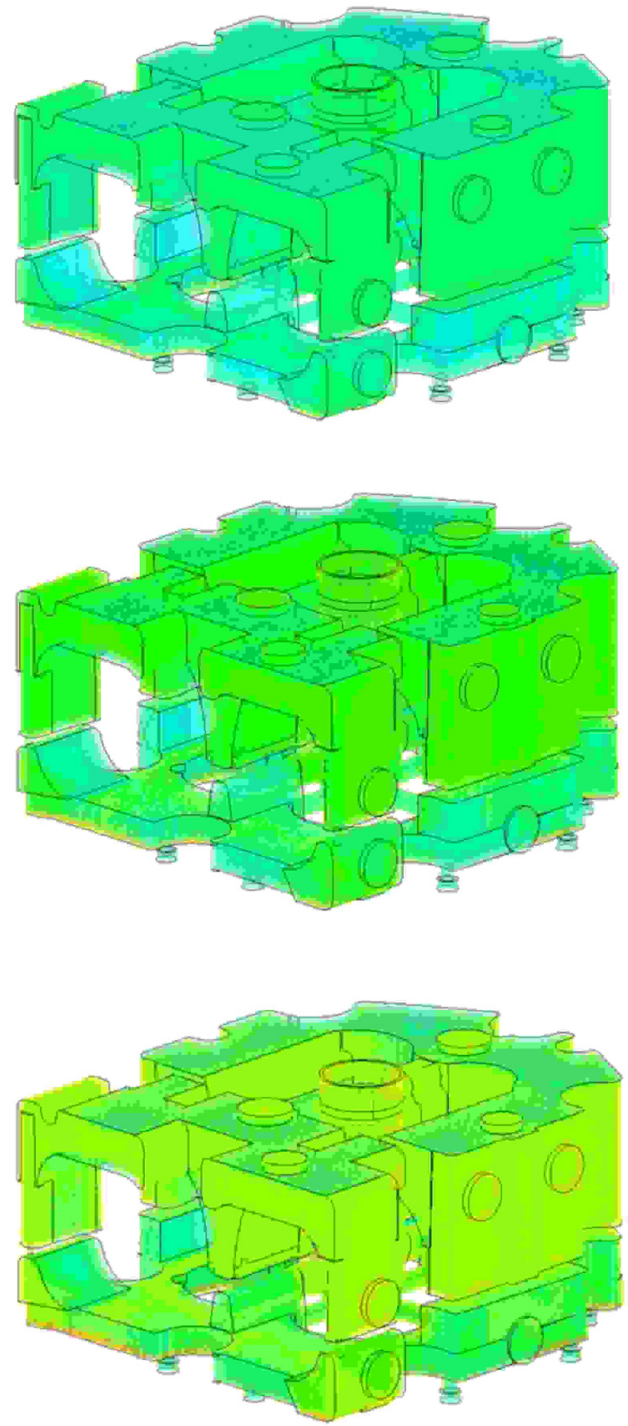

140

Fig. 4 Distribution of coolant temperature in cylinder head cooling spaces

On the surfaces adjacent to the exhaust valve seat bores, it changes within $125-140{ }^{\circ} \mathrm{C}$ (Fig. 4).

Fig. 5 shows the distribution of coolant temperature in the horizontal section of the cooling space. The results in (a)
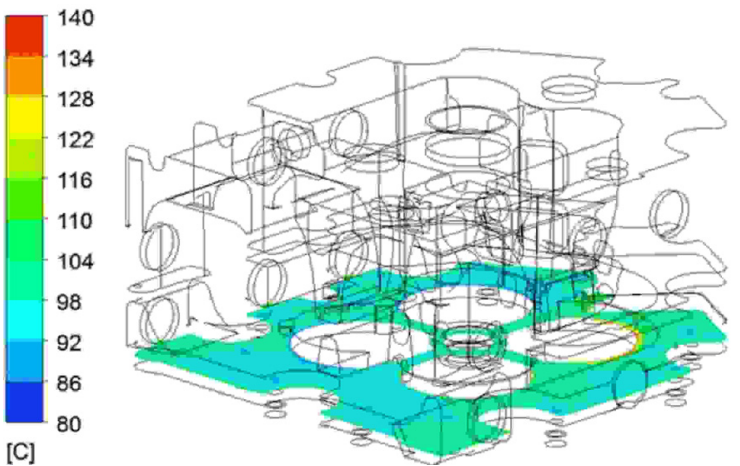

(b)

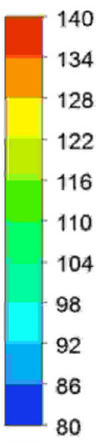

[C]

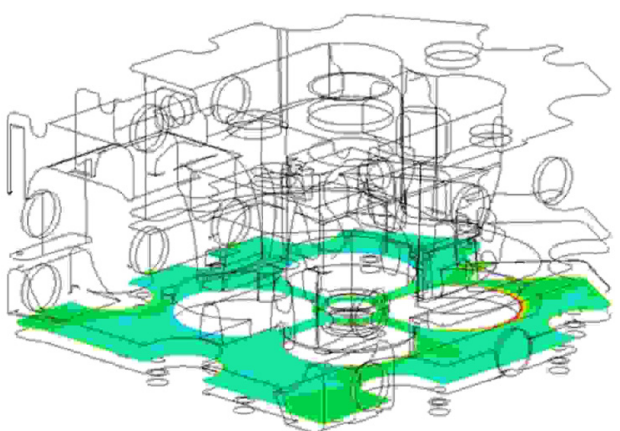

(c)

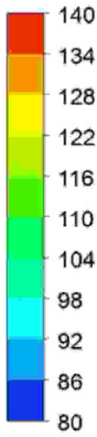

[C]

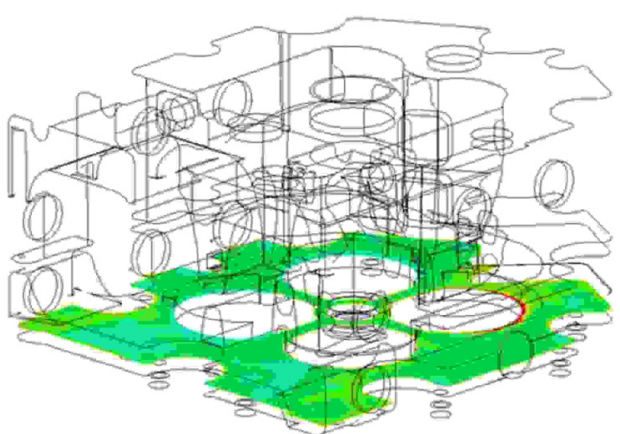

(d)

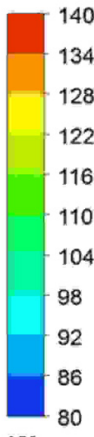

[C]

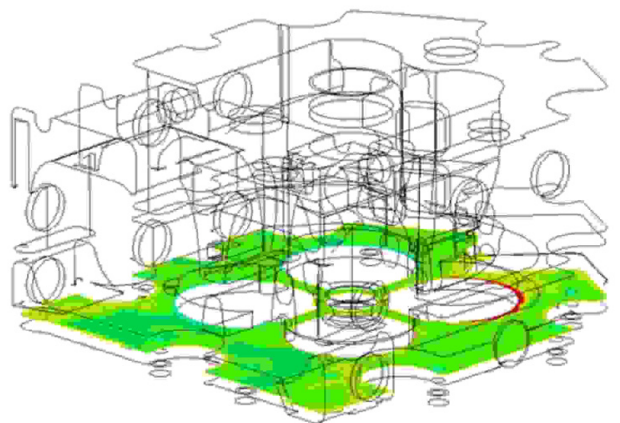

Fig. 5 Distribution of coolant temperature in the horizontal section of the cooling space

Fig. 5 show that the most critical region is that of the exhaust valve seat bores. Depending on the boost level, the coolant temperature in this region varies within 130 to $140{ }^{\circ} \mathrm{C}$. Such local coolant heating is due to the low circulation velocity 
$(0.4-1 \mathrm{~m} / \mathrm{s})$ and intensive heat transfer from exhaust gases to discharge valves, seats and the discharge duct.

A characteristic defect of the cylinder heads of boosted diesel engines during operation is the scoring mesh of cracks near exhaust valve seat bores, and heat fatigue cracks in the bridges between the valve seats bores and the fuel injector bore [15].

Fig. 6 shows the distribution of coolant pressure in the cylinder head cooling space at $\mathrm{P}_{\mathrm{e}}=1.54 \mathrm{MPa}$. As numerical simulation shows, the maximum coolant pressure $(0.152 \mathrm{MPa})$ is in the duct supplying coolant flow to the cylinder head bottom space.

In the bottom cooling space region, the pressure reaches 0.142-0.147 $\mathrm{MPa}$, and in the upper one, it varies within 0.13 to $0.14 \mathrm{MPa}$ (Fig. 6).

Fig. 7 shows the water boiling temperature vs. excessive pressure graph. For the most heated area of the cooling space - the surfaces adjacent to the exhaust valve seat bores, further increase of the boost level can cause coolant boiling and scale deposit on the walls. As is known, scale has a very low heat conductivity coefficient (about $0.2 \mathrm{~W} / \mathrm{mK}$ ). Scale deposit causes yet greater local overheating and contributes to degrading cylinder head operating conditions.

As is known, increasing the number of computational cells increases the accuracy of numerical simulation results, especially for the case of a complex configuration of the computational domain. However, this also dramatically increases computer runtime. In the following studies, the authors intend to conduct a comparative design investigation of heat-and-mass transfer processes in the cavities of the cylinder head with account of a different number of computational cells.

To ensure the effective functioning of the cooling system of the individual cylinder head in an engine with an

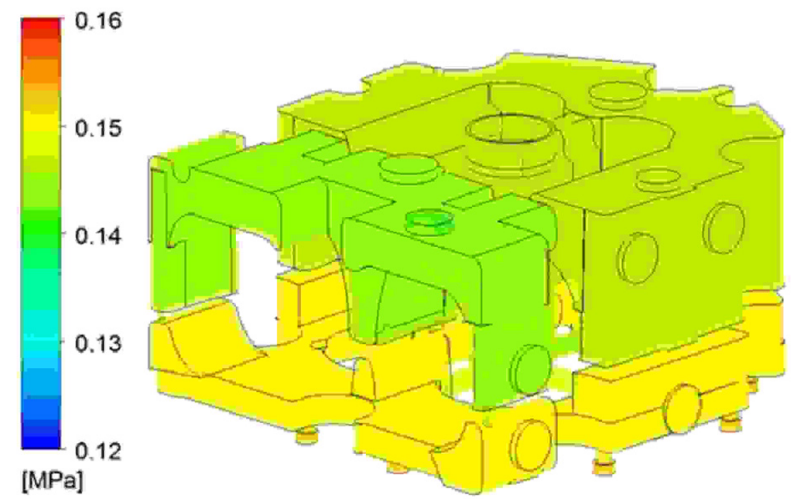

Fig. 6 Distribution of coolant pressure in the cylinder head cooling space $\left(\mathrm{P}_{\mathrm{e}}=1.54 \mathrm{MPa}\right)$ increasing boost level, it is necessary to improve the effectiveness of the cooling system, increase the area of the heat transfer surface on the cooling system side and use cast iron with a better heat conductivity coefficient.

\section{Conclusions}

The comparative study allows for the following conclusions:

- Advanced numerical methods enable investigating heat-and-mass transfer processes in ICE cooling spaces with a high level of accuracy and information content.

- With an increasing boost level of diesel engine 16 FN 26/27 from $\mathrm{P}_{\mathrm{e}}=1.54 \mathrm{MPa}$ to $\mathrm{P}_{\mathrm{e}}=1.78 \mathrm{MPa}$, the exhaust gases temperature rises from $590{ }^{\circ} \mathrm{C}$ to $700{ }^{\circ} \mathrm{C}$, and the maximum combustion pressure $\mathrm{P}_{\mathrm{z}}$ increases from $12 \mathrm{MPa}$ to $14 \mathrm{MPa}$. This has an adverse effect on the operating conditions of thermal-stressed parts of the combustion chamber.

- Comparative numerical simulation of heat-andmass transfer processes in the cylinder head cooling spaces at different engine boost levels shows that an increasing boost level degrades the operating conditions of the cylinder head.

- With a boost level increase above $\mathrm{P}_{\mathrm{e}}=1.78 \mathrm{MPa}$, the coolant can boil with scale depositing on the walls and an adverse effect on the operating conditions of the cylinder head.

- To improve the operating conditions of the cylinder head with an increasing engine boost level, it is necessary to intensify the heat transfer process by increasing the area of the heat transfer surface on the coolant side, provide additional drilled passages for coolant flow to the most thermally loaded areas, refine carburation and combustion processes, and also use cast iron with a higher heat conductivity coefficient.

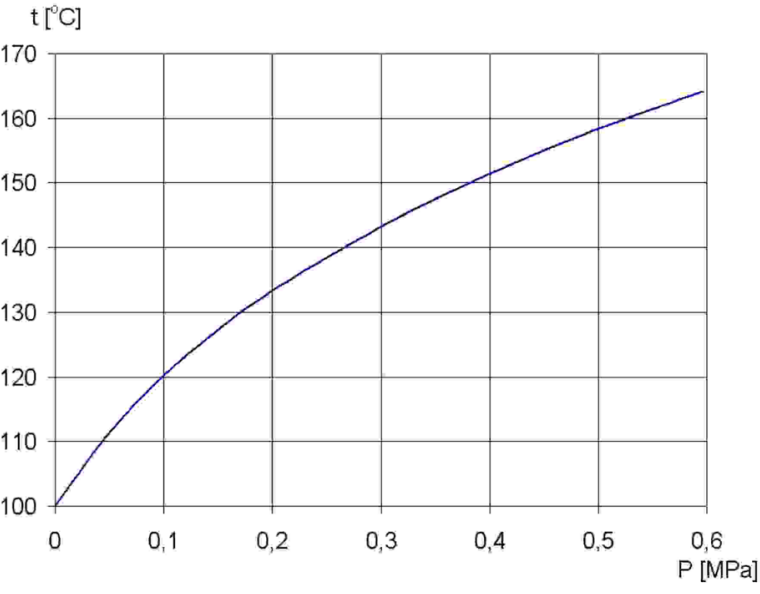

Fig. 7 Water boiling temperature vs. excessive pressure 


\section{References}

[1] Levterov, A., Savitskyi, V. "Uluchsheniye ekologicheskikh kharakteristik dizelya, rabotayushchego na biodizel'nykh toplivnykh kompozitsiyakh" (Improvement of ecological characteristics of the diesel engine working on biodiesel fuel compositions), Automobile transport: Kharkov National Automobile and Highway University, 36, pp. 110-117, 2015, [online] Available at: http://dspace.khadi. kharkov.ua/dspace/handle/123456789/1093 [Accessed: 31 August 2018] (in Russian)

[2] Wickman, D., Yun, H., Reitz, R. "Optimized Split-Spray Piston Geometry for HSDI Diesel Engine Combustion", SAE Technical Paper 2003-01-0348, 2003.

https://doi.org/10.4271/2003-01-0348

[3] Abramchuk, F. I., Avramenko, A. N. "Programmnyi kompleks dlya modelirovaniya vnutritsilindrovykh protsessov DVS" (Program complex for modelling intracylinder processes ICE), Dvigateli Vnutrennego Sgoraniya - Internal Combustion Engine, 2, pp. 7-12, 2010, [online] Available at: www.kpi.kharkov.ua/ archive/Наукова_періодика/Dvs/2010_2/rab2.pdf [Accessed: 31 August 2018] (in Russian)

[4] Zhilin, A., Zharov, A. "Chislennoye Modelirovaniye teploobmena v rubashke okhlazhdeniya dvigatelya vnutrennego sgoraniya" (Numerical Simulation of heat transfer in the cooling jacket of an internal combustion engine), Izvestiya MGTU "MAMI" - Notifications MSTU “MAMI”, 2(8), pp. 78-87, 2009, [online] Available at: http:/Мосполитех.pф/science/autotr2009/scientific/ article/s02/s02_13.pdf [Accessed: 31 August 2018] (in Russian)

[5] Munnannur, A., Abani, N., Reitz, R. "Use of a Pressure Reactive Piston to Control Diesel PCCI Operation - A Modeling Study", SAE Technical Paper 2006-01-0921, 2006.

https://doi.org/10.4271/2006-01-0921

[6] Perini, F., Zha, K., Busch, S., Reitz, R. "Comparison of Linear, Non-Linear and Generalized RNG-Based k-epsilon Models for Turbulent Diesel Engine Flows", SAE Technical Paper 2017-010561, 2017.

https://doi.org/10.4271/2017-01-0561

[7] Paratwar, A. V., Hulwan, D. B. "Surface Temperature Prediction and Thermal Analysis of Cylinder Head in Diesel Engine", International Journal of Engineering Research and Applications (IJERA), 3(4), pp. 892-902, 2013, [online] Available at: https:// pdfs.semanticscholar.org/0da8/a4b96ff086c15d37e602beed6ce00941c9d8.pdf [Accessed: 31 August 2018]
[8] Patel, N. R., Patel, D., Gajdhar, D. "A Review of computational fluid dynamics analysis of cylinder head water jacket of a diesel engine", International Research Journal of Engineering and Technology (IRJET), 4(11), pp. 1335-1338, 2017, [online] Available at: https://irjet.net/archives/V4/i11/IRJET-V4I11241.pdf [Accessed: 31 August 2018]

[9] Patil, M., Pise, A., Gokhale, N. "Simulation of Conjugate Heat Transfer (CHT) Between Engine Head and Cooling Medium of Diesel Engine", SAE Technical Paper 2015-01-1662, 2015. https://doi.org/10.4271/2015-01-1662

[10] Xu, X., Weiss, U., Gao, G. "The integration of CAD/CAM/CAE based on multi model technology in the development of cylinder head", International Journal of Automotive Technology, 3(2), pp. 47-52, 2002, [online] Available at: http://www.ijat.net/journal/ view.php?number=120 [Accessed: 31 August 2018]

[11] Basu, N., Warrier, G. R., Dhir, V. K. "Wall Heat Flux Partitioning During Subcooled Flow Boiling at Low Pressures", In: ASME 2003 Heat Transfer Summer Conference, Heat Transfer: Volume 2, Las Vegas, Nevada, USA, 2003, pp. 309-316. https://doi.org/10.1115/HT2003-47156

[12] Warrier, G. R., Dhir, V. K. "Heat Transfer and Wall Heat Flux Partitioning During Subcooled Flow Nucleate Boiling-A Review", Journal of Heat Transfer, 128(12), pp. 1243-1256, 2006. https://doi.org/10.1115/1.2349510

[13] Rosenblit, G. "Teploperedacha v dizelyakh" (Thermal transfer in diesel engines), M. Mashinostroenie, 1977, [online] Available at: https://search.rsl.ru/ru/record/01007682807 [Accessed: 31 August 2018] (in Russian)

[14] Sinenko, N., Turkach, E., Reznik, I. "Teplovoznyye dizeli tipa D70" (Diesel diesel engines of the D70 type), M. Transport, 1977, [online] Available at: http://www.pomogala.ru/books_4_teplovoz/ dizely_D70.html [Accessed: 31 August 2018] (in Russian)

[15] Linkov, O., Pylyov, V., Kravchenko, S. "Otsenka vliyaniya nagara na tenperaturnoe sostoyaniye dnishcha golovki tsilindrov sredneoborotnogo dizelya" (The estimation of carbon deposit influence on the temperature state of the middle speed diesel cylinder head), Dvigateli vnutrennego sgoraniya - Internal Combustion Engine, 1, pp. 29-32, 2016. (in Russian) https://doi.org/10.20998/0419-8719.2016.1.06 